\title{
NEUTRALIZATION OF ACIDIC SULFATES WITH AMMONIA IN VOLCANIC ORIGIN AEROSOL PARTICLES
}

\author{
J. Šakalys, E. Meinorė, and K. Kvietkus \\ State Research Institute Center for Physical Sciences and Technology, A. Goštauto 9, LT-01108 Vilnius, Lithuania \\ E-mail: ernesta.pesliakaite@gmail.com
}

Received 19 June 2015; revised 28 September 2015; accepted 25 March 2016

\begin{abstract}
Volcanic pollutants emitted during the Grimsvötn volcano eruption in Iceland on 21 May 2011 were unexpectedly captured from 24 until 29 May 2011 at the Institute of Physics, Vilnius. Measurements were performed using an Aerodyne quadrupole aerosol mass spectrometer. This paper aims to address the question whether the extent of neutralization is dependent on the aerosol particle size in submicron range particles (PM1). Data from two episodes of volcanic pollutants in advected air masses were chosen for examination. The first episode lasted from 0700 to 1400 UTC 25 May and the second episode lasted from 0400 until 1100 UTC 26 May. It was observed that the extent of acidic sulfate particle neutralization with atmospheric ammonia depends on the aerosol particle size. The extent of neutralization decreased when the particle aerodynamic diameter increased. Particles with an aerodynamic diameter of few tenths of nanometres tended to be fully neutralized and those with a consecutively increasing diameter of up to $1 \mu \mathrm{m}$ were only partially neutralized. The assessment of ambient ammonia flux onto the adjacent aerosol particle surface was performed. It was shown that the flux of ammonia can vary approximately from 30 to $74 \mu \mathrm{g} \mathrm{m}^{-2} \mathrm{~h}^{-1}$.
\end{abstract}

Keywords: Q-AMS, PM1 aerosol particles, neutralization extent, sulfuric particles, ammonia

PACS: 92.60.Mt, 92.60.Sz, 92.60.Zc

\section{Introduction}

Atmospheric aerosol particles exist as primary ones emitted from the source or secondary ones formed by nucleation, coagulation or gas-to-particle homogeneous or heterogeneous processes. Volcanic eruption favours secondary acidic aerosol formation after a large amount of sulfur dioxide is being released to the atmosphere during eruption. Volcanoes are one of the largest sulfur dioxide sources in the North Atlantic region releasing $\sim 0.9 \mathrm{Tg} \mathrm{yr}^{-1}$ of sulfuric dioxide [1]. After sulfur dioxide is oxidized with $\mathrm{OH}$, sulfuric acid is produced [2]. Particulate and gaseous volcanic emission can cause air traffic disarray (e. g. Eyjafjallajökull eruption 2010, Grimsvötn eruption 2011) and adverse effects on environment and human well-being (hazard to aircrafts, reduction of visibility). The major impact on air traffic takes effect within 24 hours and up to $1000 \mathrm{~km}$ distance from the eruption site [3], but volcanic material traces are observed even up to 100 hours and a few thousand kilometers away from the eruption site [⿰亻也 .

Perturbation of local gases and particles budget due to volcanic emission is observed farther than $3000 \mathrm{~km}$ [4-7]. Characterization and identification of volcanic origin particles are still an issue due to their ability to be mixed with pollutants present in the lower and upper atmosphere. After the eruption volcanic particu- late and gaseous emissions, e. g. sulfuric dioxide, instantly interact with atmospheric water and eventually form acidic aerosol particles. This process is followed by the acidic sulfate particle neutralization with ambient ammonia in the atmosphere. The major sources of ammonia are agricultural activities including livestock and fertilization of soil with ammonium containing compounds. Other sources of ammonia are the following: soil and ocean evaporation, industry processes and emission from transport [8]. Consequently, whether a fully neutralized or highly acidic sulfate particle is captured at the measurement site depends on the available amount of ammonia in the atmosphere while the particle is advected. The main agent of neutralization for acidic sulfate particles is ammonia. The excess of present ammonia takes part in the neutralization of organic acidic particles in the atmosphere [9], nevertheless it is also found that the presence of organic gases reduces the rate of ammonia uptake and the ambient acidic particles may longer remain in the acidic state than previously expected [10]. However, ammonia concentrations are higher in the troposphere rather than in the boundary layer [11].

In a broader context, the extent of neutralization of acidic sulfuric particles is important for estimating radiative forcing [12] that comprises a few parameters, two of which we would like to mention: ice cloud 
condensation nuclei [13] and scattering of solar radiation which generally results in atmospheric cooling [14]. Ice cloud condensation is favoured by the products of partial neutralization of acidic sulfate with ammonia: solid ammonium sulfate $\left(\mathrm{NH}_{4}\right)_{2} \mathrm{SO}_{4}$ (ammonium to sulfate molar ratio 2), ammonium bisulfate $\mathrm{NH}_{4} \mathrm{HSO}_{4}$ (ammonium to sulfate molar ratio 1.5), letovicite $\left(\mathrm{NH}_{4}\right)_{3} \mathrm{H}\left(\mathrm{SO}_{4}\right)_{2}$ (ammonium to sulfate molar ratio 1). The model presented in [11] suggests that usually neutralization of aerosols that originated in Europe is $f=0.75\left(f=\left[\mathrm{NH}_{4}^{+}\right] /\left[2 \mathrm{SO}_{4}^{2-}\right]+\left[\mathrm{NO}_{3}^{+}\right]\right.$in molar units, nitrate is almost neglected due to its low concentration) at elevation of $2 \mathrm{~km}$. In the study [15] it is demonstrated that partial neutralization depended on the particle size and was more significant than any other nanosize effect for hydroscopic growth of dry particles as small as $5.5 \mathrm{~nm}$ at the highest relative humidity (80\%). Furthermore, it was confirmed [16] that at a fixed relative humidity hygroscopic growth deteriorated as the particle diameter decreased owing to a greater extent of neutralization. An interesting observation by [17] suggests that particles of $10 \mathrm{~nm}$ diameter contain only $20-30 \%$ of sulfate, therefore it gives a strong support for the conclusion that the neutralization extent strongly depends on the particle size. In addition, the same study of [17] confirmed that the extent of neutralization of sulfate plays a key role in nucleation mechanisms in the atmosphere. In study [18] it was observed that the rate of ammonia (gas)-sulfuric acid (aerosol) chemical reaction during the neutralization was 2-fold lower for $100 \mathrm{~nm}$ diameter particles and was equal to $0.18 \pm 0.03$ whereas that for $58 \mathrm{~nm}$ diameter particles was equal to $0.40 \pm 0.10$. Other studies were also consistent with the conclusion that reaction rates decrease along with an increase of neutralization in low relative humidity.

In this study we aim to address the question whether neutralization of acidic sulfuric particles depends on the particle size in the range from a few tenths of nanometres to $1 \mu \mathrm{m}$ and to estimate the ammonia flux onto acidic sulfate particles. The chosen episode of volcanic origin particles is favourable for the assessment due to the trajectory of advected air masses which allows us to have pure volcanic origin material.

Additional analysis of the Grimsvötn volcano eruption data (24-29 May 2011) presented earlier in our paper [7] has shown that Episode 1 (25 May 2011) enables us to evaluate the mode of ammonia deposition onto volcanic aerosol particles, the extent of acidic sulfate neutralization with ammonia related to the particle size as well as provides a rough estimation of the ammonia flux onto the particle surface. In our previous paper these problems were not considered, thus we aim to address these questions and provide conclusions in the present paper.

\section{Experiments and methods}

The sampling site was located at the Institute of Physics in the vicinity of Vilnius $\left(54^{\circ} 38^{\prime} \mathrm{N} ; 24^{\circ} 11^{\prime} \mathrm{E}\right)$, about $10 \mathrm{~km}$ west of the city centre. The distance between the sampling site and the emission source at Grimsvötn in Iceland is around $3000 \mathrm{~km}$. After the eruption of the volcano the measurement period of 25-26 May 2011 (in this paper) was selected for data analysis [ 7 ].

The concentration and chemical composition of PM1 were determined with an Aerodyne quadrupole aerosol mass spectrometer (Q-AMS). The Q-AMS provides the real-time chemical composition and mass size distribution of non-refractory chemical components (sulfate $\mathrm{SO}_{4}^{2-}$, ammonium $\mathrm{NH}_{4}^{+}$, nitrate $\mathrm{NO}_{3}^{-}$ and organics) present in ambient atmospheric aerosol particles at a temporal resolution of $5 \mathrm{~min}$. A detailed description of the AMS, its operation and calibration are given in several studies [19-21] and in our publications 㭌, , 22, 23].

During the 25-26 May 2011 period forward and backward trajectories were calculated for the sites (Grimsvötn and Vilnius) using the National Oceanic and Atmospheric Administration (NOAA) Hybrid Single-Particle Lagrangian Integrated Trajectory (HYSPLIT) model [24]. Forward and backward trajectories were analyzed at various arrival heights above the ground level (AGL).

The Monte-Carlo method was applied in order to evaluate the standard geometrical deviation of the median diameter values. The Monte-Carlo method is a probabilistic computational algorithm. Random numbers are generated in order to obtain a new sequence of lognormal distribution which has the same descriptive values as the experimentally obtained lognormal distribution. The main idea of the method is that the simulated system has the same descriptive values (i. e. average value, standard geometrical deviation) as the system with randomly obtained values [25].

\section{Results and discussion}

The time series of hourly averaged concentrations of sulfate $\mathrm{SO}_{4}^{2-}$ and ammonium $\mathrm{NH}_{4}^{+}$during the 2526 May 2011 period are presented in Fig. 1. Two concentration episodes were selected for an additional analysis: 0700-1400 UTC 25 May (Episode 1) and 0400-1100 UTC 26 May (Episode 2).

During Episode 1 the air masses trajectory passed at relatively high altitudes avoiding the polluted industrial regions of Europe (see Fig. 2(a)). Figure 2(a) indicates that the air masses containing the volcanic pollutants descended to the surface from $3000-4000 \mathrm{~m}$ of troposphere. The dispersion of the plume (Episode 1) was 


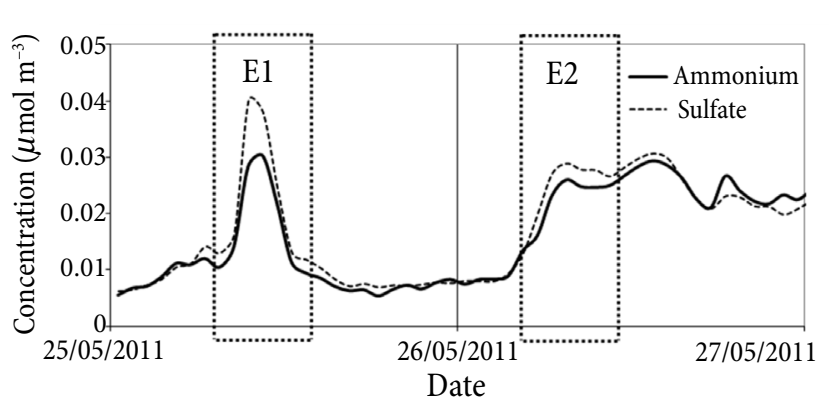

Fig. 1. Time series of hourly averaged concentrations of sulfate $\mathrm{SO}_{4}^{2-}$ and ammonium $\mathrm{NH}_{4}^{+}$during the periods 0700-1400 UTC 25 May (Episode 1) and 0400-1100 UTC 26 May (Episode 2).

very small over the Atlantic Ocean and we observed an increase of the sulfate and ammonium concentration. During Episode 2 the air masses trajectory passed at considerably lower altitudes and resulted in a mix of volcanic pollutants with previous volcanic emissions and pollutants of anthropogenic origin (see Fig. 2(b)). The trajectory of air masses over the regions of Ireland, UK and Northern Germany has passed over at relatively low altitudes. The higher altitude trajectory indicates air masses which arrived with pollutants emitted from the volcano on May 23, $1800 \mathrm{H}$. These two episodes allow us to compare and evaluate neutralization peculiarities of acidic sulfate particles with ammonia.

Volcanoes emit a variety of gases and particles. Acidic sulfate aerosols are formed as a result of homogeneous and heterogeneous chemical reactions of sulfur dioxide in the atmosphere [26, 27]. Ammonia compounds interact with acidic sulfate aerosols in the atmosphere. The size-resolved distribution spectra of $\mathrm{NH}_{4}^{+}$and $\mathrm{SO}_{4}^{2-}$ molar concentrations during Episodes 1 and 2 are presented in Fig. 3. In both cases the distribution of concentrations is lognormal.

The Monte-Carlo method is applied in order to obtain a standard geometrical deviation of the median diameter. It is done in order to evaluate steadiness of the obtained distribution spectra of $\mathrm{NH}_{4}^{+}$and $\mathrm{SO}_{4}^{2-}$ molar concentrations during Episodes 1 and 2 (Fig. 3). Random numerical values of the new lognormal distribution corresponding to the average values and standard deviations of distribution spectra presented in Fig. 3 are generated. The obtained new lognormal distribution yields new median values. The procedure is repeated 36 times. The obtained median values allow us to evaluate the standard geometrical deviation values of the simulated system. According to the calculated values of particle median diameters and their standard geometrical deviations, the extent of neutralization on the particle size of $\mathrm{NH}_{4}^{+}$and $\mathrm{SO}_{4}^{2-}$ is calculated (Fig. 4). One can see that in the aerosol particles with a diameter below $100 \mathrm{~nm}$ the acidic sulfates are fully neutralized with ammonia (ratio is 1 ), however, for larger particles the neutralization extent is declining. In other words, to neutralize one mole of $\mathrm{SO}_{4}^{2-}$ two moles of $\mathrm{NH}_{3}$ are needed. The neutralization extent of $\left(\mathrm{NH}_{4}\right)_{2 \mathrm{X}} \mathrm{H}_{2(1-\mathrm{X})} \mathrm{SO}_{4}$ acidic sulfate particles (where the neutralization extent $X=M_{\mathrm{NH}_{4}^{+}} / 2 M_{\mathrm{SO}_{4}^{2-}} \times 100 \%, M_{\mathrm{NH}_{4}^{+}}$is the molar concentration of $\mathrm{NH}_{4}^{+}$and $M_{\mathrm{SO}_{4}^{2-}}$ is the molar
Forward trajectories starting at 2000 UTC 21 May 11 GDAS meteorological data

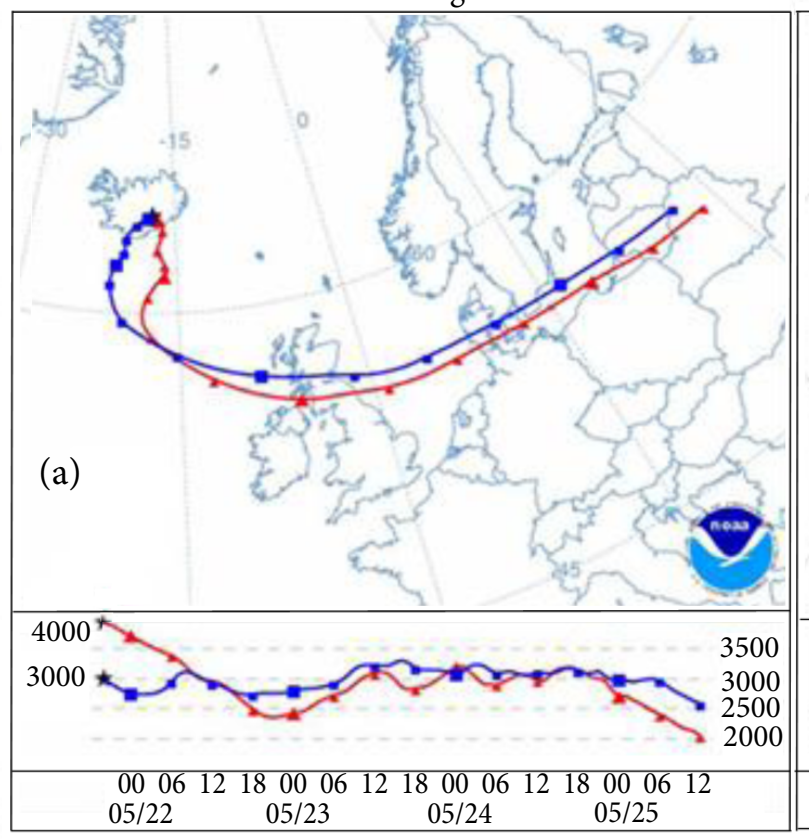

Backward trajectories ending at 0700 UTC 26 May 11 GDAS meteorological data

(b)

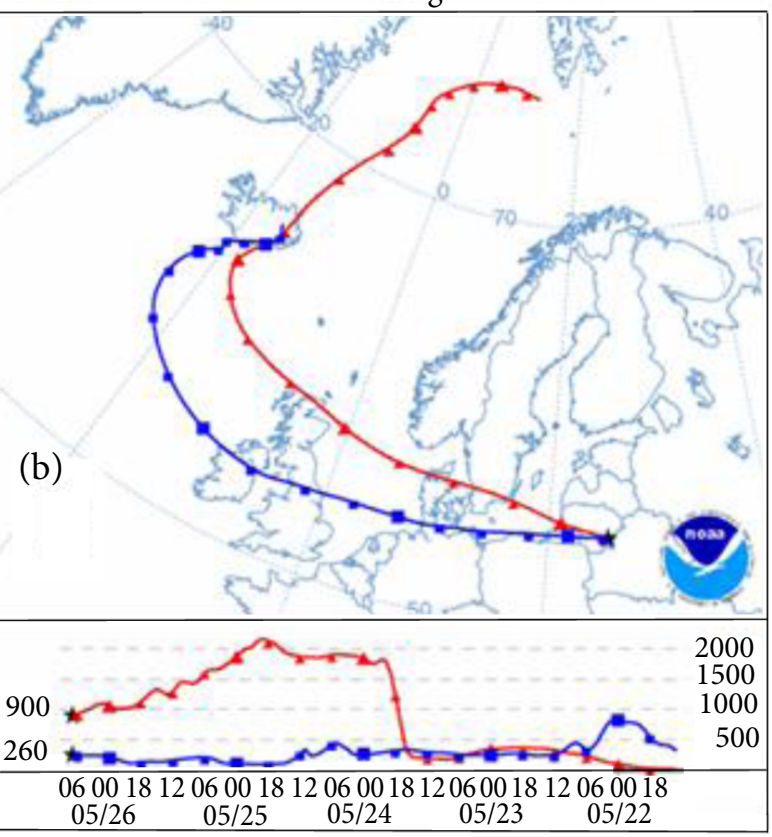

Fig. 2. Forward and backward trajectories of air masses during Episodes 1 (a) and 2 (b). 

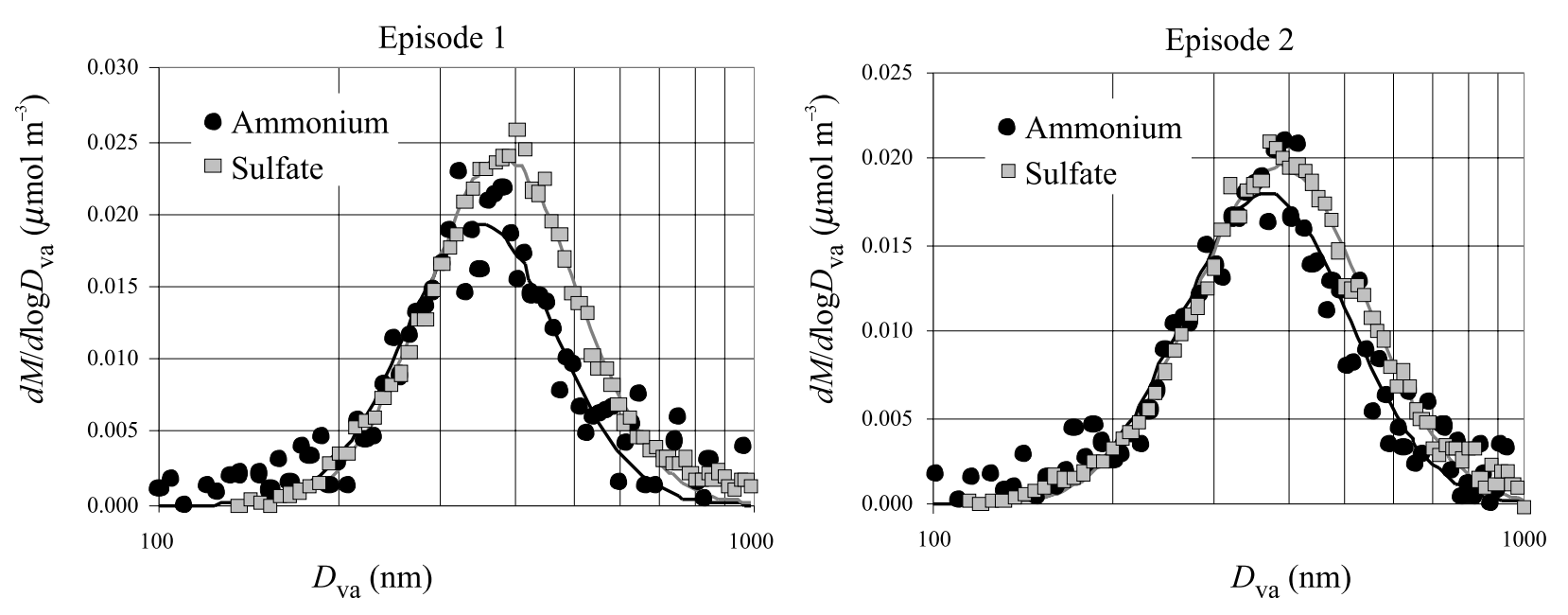

Fig. 3. Size-resolved distribution spectra of sulfate and ammonium molar concentrations during Episodes 1 and 2.

concentration of $\mathrm{SO}_{4}^{2-}$ ) related to the aerosol particle size is depicted in Fig. 4 .

During Episode 2 (Fig. 1) the peaks of sulfate and ammonium are not as sharp as during Episode 1 and this is related with the very first eruption hours when emitted pollutants were relatively at high altitudes of the troposphere and reached the measurement site without any contact with industrial regions. The emitted pollutants (Episode 2) later got mixed with earlier emitted pollutants from the volcano and low altitude air masses contacted with the polluted air above industrial regions of Ireland, UK, and northern Germany.

The data analysis of Episode 1 provides a rough estimation of the ammonia flux onto the aerosol particle surface. The lognormal distribution of the aerosol particle number according to their size is related with the volumetric and surface area distribution

$$
\ln D_{\mathrm{m} V}-\ln D_{\mathrm{mS}}=\ln ^{2} \sigma
$$

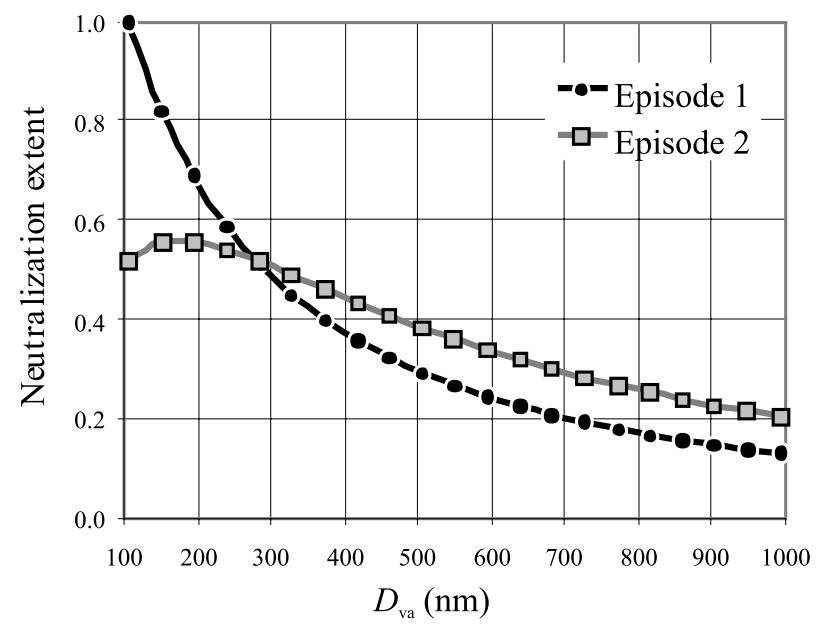

Fig. 4. Extent of acidic sulfate neutralization with ammonia related to the aerosol particle size during Episodes 1 and 2. where $D_{\mathrm{m} V}$ is the volumetric median diameter distribution, $D_{\mathrm{m} S}$ is the surface area median diameter distribution, and $\ln \sigma$ is the geometrical standard deviation. Thus,

$$
D_{\mathrm{mV}}=D_{\mathrm{m} S} \mathrm{e}^{\ln ^{2} \sigma} \text { or } D_{\mathrm{m} S}=D_{\mathrm{mV}} \mathrm{e}^{-\ln ^{2} \sigma} \text {. }
$$

The lognormal distribution of the median diameter magnitude and its error estimation were performed by applying the Monte-Carlo method.

The median diameter value of lognormal distribution of ammonium and sulfate concentrations in aerosol particles and values obtained using Eq. (2) are presented in Table 1. It is seen that during Episode 1 the corrected median diameter value of ammonium-containing particles (within the limits of error) very well coincides with the median diameter value of sulfate-containing particles $(381.0 \pm 4.6$ and $379.6 \pm 1.2 \mathrm{~nm}$ ) and, on the contrary, the corrected median diameter value of sulfate-containing particles (within the limits of error) is consistent with the median diameter value of ammonium-containing particles $(346.7 \pm 1.3$ and $349.0 \pm 3.4 \mathrm{~nm})$. This indicates that $\mathrm{NH}_{4}^{+}$and $\mathrm{SO}_{4}^{2-}$ particles are of the same origin, having the same lognormal distribution diameter number, and that ammonia is deposited on the surface area of aerosol particles containing sulfates during transfer with the air masses to the measurement site. In Episode 2 the abovementioned coincidence is not observed because air masses from this episode were mixed with older air masses.

A rough estimation of the ammonia flux onto the aerosol particle surface has been made using the data of Episode 1. During this episode the average $\mathrm{NH}_{4}^{+}$concentration was $0.83 \mu \mathrm{g} \mathrm{m}^{-3}$ and that of $\mathrm{SO}_{4}^{2-}$ was $6.02 \mu \mathrm{g} \mathrm{m}^{-3}$. The influence of nitrates was neglected due to the low mass $(0.5 \%)$ compared with 
Table 1. The median diameter value of lognormal distribution of $\mathrm{NH}_{4}^{+}$and $\mathrm{SO}_{4}^{2-}$ concentrations and their standard deviations during Episodes 1 and 2.

\begin{tabular}{cccc}
\hline \multicolumn{3}{c|}{$\mathrm{NH}_{4}^{+}$} & \multicolumn{2}{c}{$\mathrm{SO}_{4}^{2-}$} \\
\hline$D_{\mathrm{m}}, \mathrm{nm} \quad D_{\mathrm{m}} \mathrm{e}^{\ln ^{2} \sigma_{\mathrm{NH}_{4}^{+}}}, \mathrm{nm} \quad D_{\mathrm{m}}, \mathrm{nm}$ & $D_{\mathrm{m}} \mathrm{e}^{-\ln ^{2} \sigma_{\mathrm{SO}_{4}^{2-}}, \mathrm{nm}}$ \\
\hline \multicolumn{4}{c}{ Episode 1} \\
\hline $349.0 \pm 3.4$ & $381.0 \pm 4.6$ & $379.6 \pm 1.2$ & $346.7 \pm 1.3$ \\
\hline \multicolumn{4}{c}{ Episode 2} \\
\hline
\end{tabular}

the mass of all chemical components. The mass of elemental carbon (EC) made up $20 \%$ of the organic carbon mass (OC) [28-30]. Based on literature data [31] it has been accepted that the density of ammonium is $1.75 \mathrm{~g} \mathrm{~cm}^{-3}$, that of sulfate is $1.78 \mathrm{~g} \mathrm{~cm}^{-3}$, the density of organics is $1.5 \mathrm{~g} \mathrm{~cm}^{-3}$, the density of elemental carbon is $1.77 \mathrm{~g} \mathrm{~cm}^{-3}$ [32] and that of water is $1.0 \mathrm{~g} \mathrm{~cm}^{-3}$. The water mass was calculated after evaluation of the aerosol particle growing factor due to humidity. When the humidity is close to $50-60 \%$ and the temperature is about $12-15^{\circ} \mathrm{C}$, the aerosol particle growth factor, based on literature data, is from 1.2 to 1.5 [33]. Using the above data, the resultant aerosol particle densities were evaluated:

$$
\rho\left(D_{\mathrm{va}}\right)=\frac{\sum_{i=1}^{n} m_{i}\left(D_{\mathrm{va}}\right)}{\sum_{i=1}^{n} \frac{m_{i}\left(D_{\mathrm{va}}\right)}{\rho_{0 i}}} .
$$

Here $m_{i}\left(D_{\mathrm{va}}\right)$ is the mass of the aerosol particle chemical component $i$ with the vacuum aerodynamic diameter $D_{\text {va }}$, and $\rho_{0 i}$ is the density of the chemical component $i$.

Based on the calculated densities the diameters of aerosol particles were corrected:

$$
D=\frac{\rho_{0}}{\rho\left(D_{\text {va }}\right)} D_{\text {va }} .
$$

Here $\rho_{0}$ is the water density.

Values from Q-AMS, $\frac{\mathrm{d} m_{\mathrm{i}}\left(D_{\mathrm{va}}\right)}{\mathrm{d} \log D_{\mathrm{va}}}$ were calculated based on the corrected diameters:

$$
\frac{\mathrm{d} m_{i}(D)}{\mathrm{d} \ln D}=\frac{1}{\ln (10)} \cdot \frac{\mathrm{d} m_{i}\left(D_{\text {va }}\right)}{\mathrm{d} \log D_{\text {va }}} \cdot \frac{\Delta \ln D_{\text {va }}}{\Delta \ln D} .
$$

Aerosol particle masses were defined by

$$
m(D)=\frac{1}{6} \rho(D) \pi D^{3} .
$$

The size resolved particle number distribution was calculated considering their diameter:

$$
\frac{\mathrm{d} n}{\mathrm{~d} \ln D}=\frac{1}{m(D)} \sum_{i=1}^{n} \frac{\mathrm{d} m_{i}(D)}{\mathrm{d} \ln D} .
$$

The particle surface area is equal to $s=\pi D^{2}$, then

$$
\frac{\mathrm{d} S}{\mathrm{~d} \ln D}=\pi D^{2} \frac{\mathrm{d} n}{\mathrm{~d} \ln D} \text {. }
$$

The whole particle surface area in the mode is equal to

$$
S=\int_{D_{1}}^{D_{2}} \frac{\mathrm{d} S}{D \mathrm{~d} \ln D} \mathrm{~d} D
$$

By dividing the $\mathrm{NH}_{4}^{+}$amount in the mode $m_{\mathrm{am}}$ to the surface area $S$ of all particles in the mode and into time $T$ during which aerosol particles were transported with air masses to the measurement point, we obtain the value of $\mathrm{NH}_{4}^{+}$flux to the particle surface area:

$$
\frac{\mathrm{d} m}{\mathrm{~d} S \mathrm{dt}}=\frac{m_{\mathrm{am}}}{S T} \cdot \frac{\mu_{\mathrm{NH}_{3}}}{\mu_{\mathrm{NH}_{4}^{+}}}\left(\mu_{\mathrm{NH}_{3}}\right. \text { is moles of ammonia, }
$$

$\mu_{\mathrm{NH}_{4}^{+}}$is moles of ammonium).

The duration of aerosol particles being advected with the air masses to the measurement point was $86 \pm 4$ hours. According to these data the $\mathrm{NH}_{4}^{+}$flux to the particle surface area has been evaluated to be from 30 to $55 \mu \mathrm{g} \mathrm{m}^{-2} \mathrm{~h}^{-1}$ (if we assume that particles were dry all the time, the flux would be $74 \mu \mathrm{g} \mathrm{m}^{-2} \mathrm{~h}^{-1}$ ). The above presented average values are approximate because the meteorological conditions during the transport of air masses were unknown. Probably the highest flux was when aerosol particles were transported at the lowest atmospheric height. Thus, in this case the flux value would be higher. The expected time of life for aerosol particles in the atmosphere with the diameter below $1 \mu \mathrm{m}$ is on the average 7 days [34]. This implies that the neutralization of volcanic origin acidic sulfate particles with ammonia is partial and that the acidic particles of volcanic origin favour the formation of acidic precipitation.

\section{Conclusions}

Acidic sulfates on volcanic origin aerosol particles can be fully neutralized with atmospheric ammonia when their size is of about tenths of nanometres, whereas larger particles have a lower extent of neutralization. Therefore, the neutralization of acidic sulfates with ammonia in the volcanic origin aerosol particles can be estimated only based on the size of aerosol particles. The volcanic origin aerosol particles favour the formation of acidic precipitation. 
The atmospheric ammonia flux to the aerosol particle surface area, depending on meteorological conditions, can vary approximately from 30 to $74 \mu \mathrm{g} \mathrm{m}^{-2} \mathrm{~h}^{-1}$.

\section{Acknowledgements}

We are grateful to Prof. A. Undzenas for the valuable remarks during the preparation of the manuscript.

\section{References}

[1] M.M. Halmer, H.-U. Schmincke, and H.-F. Graf, The annual volcanic gas input into the atmosphere, in particular into the stratosphere: a global data set for the past 100 years, J. Volcanol. Geotherm. Res. 115, 511-528 (2002).

[2] S. Solomon, D. Qin, M. Manning, Z. Chen, M. Marquis, K.B. Averyt, M. Tignor, and H.L. Miller, Climate Change 2007: The Physical Science Basis, Contribution of Working Group I to the Fourth Assessment Report of the Intergovernmental Panel on Climate Change (Cambridge University Press, Cambridge, United Kingdom and New York, NY, USA, 2007), https:// www.ipcc.ch/pdf/assessment-report/ar4/wg1/ar4wg1-frontmatter.pdt, accessed: January 2015.

[3] M. Guffanti, T.J. Casadevall, and K. Budding, Encounters of Aircraft with Volcanic Ash Clouds: a Compilation of Known Incidents 1953-2009, U.S. Geological Survey Data Series 545, Version 1.0, plus 4 appendixes including the Compilation Database (2010), http://pubs.usgs.gov/ds/545, accessed: January 2015.

[4] J.A. Adame, M.D. Valenti-Pia, and M. Gil-Ojeda, Impact evaluation of potential volcanic plumes over Spain, Atmos. Res. 160, 39-49 (2015), http://dx.doi. org/10.1016/j.atmosres.2015.03.002

[5] J. Ovadnevaite, D. Ceburnis, K. Plauskaite-Sukiene, R. Modini, R. Dupuy, I. Rimselyte, R. Ramonet, K. Kvietkus, Z. Ristovski, H. Berresheim, and C. O'Dowd, Volcanic sulphate and Arctic dust plumes over the North Atlantic Ocean, Atmos. Environ. 43(32), 4968-4974 (2009).

[6] V.M. Kerminen, J.V. Niemi, H. Timonen, M. Aurela, A. Frey, S. Carbone, S. Saarikoski, K. Teinilä, J. Hakkarainen, J. Tamminen, J. Vira, M. Prank, M. Sofiev, and R. Hillamo, Characterization of a volcanic ash episode in southern Finland caused by the Grimsvötn eruption in Iceland in May 2011, Atmos. Chem. Phys. 11, 12227-12239 (2011).

[7] K. Kvietkus, J. Šakalys, J. Didžbalis, I. Garbarienè, N. Špirkauskaite, and V. Remeikis, Atmospheric aerosol episodes over Lithuania after the May 2011 volcano eruption at Grimsvötn, Iceland, Atmos. Res. 122, 93-101 (2013).

[8] S.N. Behera, M. Sharma, V.P. Aneja, and R. Balasubramanian, Ammonia in the atmosphere: a review on emission sources, atmospheric chemistry and deposition on terrestrial bodies, Environ. Sci. Pollut. Res. 20(11), 8092-8131 (2013).

[9] A.A. Mensah, R. Holzinger, R. Otjes, A. Trimborn, Th.F. Mentel, H. ten Brink, B. Henzing, and A. Kiendler-Scharr, Aerosol chemical composition at Cabauw, The Netherlands as observed in two intensive periods in May 2008 and March 2009, Atmos. Chem. Phys. 12(10), 4723-4742 (2011), http://dx.doi.org/10.5194/acpd-11-27661-2011

[10]J. Liggio, S.-M. Li, A. Vlasenko, C. Stroud, and P. Makar, Depression of ammonia uptake to sulfuric acid aerosols by competing uptake of ambient organic gases, Environ. Sci. Technol. 45(7), 27902796 (2011), http://dx.doi.org/10.1021/es103801g

[11]J.A. Fisher, D.J. Jacob, Q. Wang, R. Bahreini, C.C. Carouge, M.J. Cubison, J.E. Dibb, T. Diehl, J.L. Jimenez, E.M. Leibensperger, M.B.J. Meinders, H.O.T. Pye, P.K. Quinn, S. Sharma, A. van Donkelaar, and R.M. Yantosca, Sources, distribution, and acidity of sulfate-ammonium aerosol in the Arctic in winterspring, Atmos. Environ. 45, 7301-7318 (2011).

[12]S.T. Martin, H.M. Hung, R.J. Park, D.J. Jacob, R.J.D. Spurr, K.V. Chance, and M. Chin, Effects of the physical state of tropospheric ammonium-sulfate-nitrate particles on global aerosol direct radiative forcing, Atmos. Chem. Phys. 4, 183-214 (2004).

[13]K.J. Baustian, M.E. Wise, and M.A. Tolbert, Depositional ice nucleation on solid ammonium sulfate and glutaric acid particles, Atmos. Chem. Phys. 10, 2307-2317 (2010).

[14]P.K. Quinn, T.S. Bates, E. Baum, N. Doubleday, A.M. Fiore, M. Flanner, A. Fridlind, T.J. Garrett, D. Koch, and S. Menon, Short-lived pollutants in the Arctic: their climate impact and possible mitigation strategies, Atmos. Chem. Phys. 8, 1723-1735 (2008).

[15]G. Biskos, P.R. Buseck, and S.T. Martin, Hygroscopic growth of nucleation-mode acidic sulfate particles, Aerosol. Sci. 40, 338-347 (2009).

[16]L. Skrabalova, D. Brus, T. Anttila, V. Zdimal, and $\mathrm{H}$. Lihavainen, Growth of sulphuric acid nanoparticles under wet and dry conditions, Atmos. Chem. Phys. 14, 6461-6475 (2014), http://dx.doi. org/10.5194/acp-14-6461-2014

[17]M. Kulmala, L. Laakso, K.E.J. Lehtinen, I. Riipinen, M. Dal Maso, T. Anttila, V.-M. Kerminen, U. Horrak, M. Vana, and H. Tammet, Initial steps of aerosol growth, Atmos. Chem. Phys. 4, 2553-2560 (2004).

[18]P.H. Mcmurry, H. Takano, and G.R. Anderson, Study of the ammonia (gas)-sulfuric acid (aerosols) reaction rate, Environ. Sci. Technol. 17(6) (1983).

[19]J.T. Jayne, D.C. Leard, X.F. Zhang, P. Davidovits, K.A. Smith, C.E. Kolb, and D.R. Worsnop, Development of an aerosol mass spectrometer for size and composition analysis of submicron particles, Aerosol Sci. Technol. 33(1-2), 49-70 (2000).

[20]J.L. Jimenez, J.T. Jayne, Q. Shi, C.E. Kolb, D.R. Worsnop, I. Yourshaw, J.H. Seinfeld, R.C. Flagan, 
X.F. Zhang, K.A. Smith, J.W. Moris, and P. Davidovits, Ambient aerosol sampling using the aerodyne aerosol mass spectrometer, J. Geophys. Res. 108(D7), 8245-8258 (2003).

[21]J.D. Allan, J.L. Jimenez, P.I. Williams, M.R. Alfara, K.N. Bower, J.T. Jane, H. Coe, and D.R. Worsnop, Quantitative sampling using Aerodyne aerosol mass spectrometer: 1 . Techniques of data interpretation and error analysis, J. Geophys. Res. 108(D3), 4090-4100 (2003).

[22]K. Kvietkus, J. Šakalys, I. Rimšelytė, J. Ovadnevaitė, V. Remeikis, and V. Špakauskas, Characterization of aerosol sources at urban and background sites in Lithuania, Lith. J. Phys. 51(1), 65-74 (2011).

[23]I. Garbarienè, K. Kvietkus, J. Šakalys, J. Ovadnevaitè, and D. Čeburnis, Biogenic and anthropogenic organic matter in aerosol over Continental Europe: source characterization in the east Baltic region, J. Atmos. Chem. 69(2), 159-174 (2012).

[24]R.R. Draxler and G.D. Rolph, HYSPLIT (Hybrid Single-Particle Lagrangian Integrated Trajectory) Model Access via National Oceanic and Atmospheric Administration (NOAA) ARL READY Website (NOAA Air Resources Laboratory, College Park, MD, 2003), http://ready.arl.noaa.gov/HYSPLIT. php accessed: February 2015.

[25]N. Metropolis and S. Ulam, The Monte Carlo Method, J. Amer. Stat. Assoc. 44, 335-341 (1949).

[26]R. Glasow, N. Bobrowski, and C. Kern, The effects of volcanic eruptions on atmospheric chemistry, Chem. Geol. 263, 131-142 (2009).

[27]H. Bao, S. Yu, and D.Q. Tong, Massive volcanic $\mathrm{SO}_{2}$ oxidation and sulfate aerosol deposition in Cenozoic North America, Nature 465, 909-912 (2010).

[28]T.H. Gan, P. Hield, B. Boere, M. Bentley, T. Cogdon, P.J. Hanhela, B. Anderson, and R. Gillett, in:
Proceedings of 15th ETH-Conference on Combustion Generated Nanoparticles (Zurich, Switzerland, June 26-29, 2011).

[29]B.J. Turpin and H.J. Lim, Species contributions to PM2.5 mass concentrations: Revisiting common assumptions for estimating organic mass, Aerosol Sci. Technol. 35(1), 602-610 (2001).

[30]L. Xing, T.M. Fu, J.J. Cao, S.C. Lee, G.H. Wang, K.F. Ho, M.C. Cheng, C.F. You, and T.J. Wang, Seasonal and spatial variability of the OM/OC mass ratios and high regional correlation between oxalic acid and zinc in Chinese urban organic aerosols, Atmos. Chem. Phys. 13, 4307-4318 (2013).

[31] C. Mohr, P.F. DeCarlo, M.F. Heringa, R. Chirico, J.G. Slowik, R. Richter, C. Reche, A. Alastuey, X. Querol, R. Seco, J. Peñuelas, J.L. Jiménez, M. Crippa, R. Zimmermann, U. Baltensperger, and A.S.H. Prévôt, Identification and quantification of organic aerosol from cooking and other sources in Barcelona using aerosol mass spectrometer data, Atmos. Chem. Phys. 12, 1649-1665 (2012).

[32]Q. Zhang, M.R. Canagaratna, J.T. Jayne, D.R. Worsnop, and J.L. Jimenez, Time- and size-resolved chemical composition of submicron particles in Pittsburgh: Implications for aerosol sources and processes, J. Geophys. Res. 110, D07S09 (2005), http://dx.doi.org/10.1029/2004JD004649

[33]J.M. Flores, R.Z. Bar-Or, N. Bluvshtein, A. AboRiziq, A. Kostinski, S. Borrmann, I. Koren, and Y. Rudich, Absorbing aerosols at high relative humidity: linking hygroscopic growth to optical properties, Atmos. Chem. Phys. 12, 5511-5521 (2012), http://dx.doi.org/10.5194/acp-12-5511-2012

[34]R. Jeanicke, Atmospheric aerosols and global climate, J. Aerosol Sci. 11, 577-588 (1980).

\title{
VULKANINĖS KILMĖS RŪGŠTINIŲ SULFATỤ NEUTRALIZACIJA AMONIAKU AEROZOLIO DALELĖSE
}

\author{
J. Šakalys, E. Meinorè, K. Kvietkus \\ Valstybinis moksliniu tyrimu institutas Fiziniu ir technologijos mokslu centras, Vilnius, Lietuva
}

\section{Santrauka}

Matavimai buvo atlikti Vilniuje, Fizinių ir technologijos mokslų centro Fizikos institute. Duomenų analizei buvo pasirinkti du epizodai $2011 \mathrm{~m}$. gegužès mèn. 2526 d., kai oro masès į matavimo vietą atnešè išsiveržusio Grimsvötn vulkano išmestus teršalus. Submikroninès aerozolio dalelių (PM1) frakcijos cheminè sudètis ir cheminių komponenčių koncentracijos pasiskirstymas pagal aerozolio dalelių dydi buvo nustatyti AERODYNE kvadrupoliniu aerozolio masès spektrometru (Q-AMS). Remiantis eksperimento duomenimis, buvo ịvertintas rūgštinių sulfatų neutralizacijos amoniaku laipsnis. Pirmojo epizodo metu mažesnèse nei $100 \mathrm{~nm}$ aerozolio dalelèse rūgštiniai sulfatai visiškai neutralizuoti amoniaku, o kuo dalelès didesnès, tuo neutralizacijos laipsnis mažesnis. Antrojo epizodo metu vaizdas ne toks ryškus, nes su oro masèmis buvo atnešti susimaišę pirmosiomis ir vèlesnèmis valandomis išmesti teršalai. Pirmojo epizodo amonio ir sulfatų koncentracijos aerozolio dalelèse logaritminio normalinio pasiskirstymo pagal jų dydi analizè parodé, kad atmosferoje esantis amoniakas pateko ant rūgštinių sulfatų turinčių dalelių paviršiaus pakeliui su oro masèmis joms keliaujant iki matavimų vietos. Šio epizodo duomenys leidžia įvertinti amoniako srautą i aerozolio daleliu paviršių. Vidutinis amoniako srautas ị daleliu paviršiu buvo $30-74 \mu \mathrm{g} \mathrm{m} \mathrm{m}^{-2} \mathrm{~h}^{-1}$. Šias vidutines vertes reikètu vertinti atsargiai, nes meteorologinès sąlygos, lydejusios ateinančias oro mases, nebuvo žinomos. 